\title{
Clinical and Salivary Findings in Patients with Different Types of Orthodontic Brackets
}

\section{Klinički i salivarni nalazi pacijenata s različitim tipovima ortodontskih bravica}

\author{
${ }^{1}$ Private dental practice, Zagreb, Croatia \\ Privatna stomatološka ordinacija, Zagreb, Hrvatska \\ 2 Department of Clinical and Molecular Microbiology, University Hospital Centre Zagreb, School of Medicine University of Zagreb, Zagreb, \\ Croatia \\ Zavod za kliničku molekularnu mikrobiologiju Medicinskog fakulteta i Klinički bolnički centar Zagreb Sveučilišta u Zagrebu \\ 3 Department of Oral Medicine, School of Dental Medicine, University of Zagreb, Zagreb, Croatia \\ Zavod za oralnu medicinu Stomatološkog fakulteta Sveučilišta u Zagrebu \\ ${ }^{4}$ Department of Restorative Dentistry, School of Dental Medicine, University of Zagreb, Zagreb, Croatia \\ Zavod za endodonciju i restaurativnu dentalnu medicinu Stomatološkog fakulteta Sveučilišta u Zagrebu
}

\section{Abstract}

Aim: Data regarding different types of orthodontic brackets and ligation and various clinical and salivary findings are scarce. Therefore, the aim of this study was to compare clinical and salivary findings in patients with different types of fixed orthodontic appliances. Subjects and methods: Decayed, missing and filled teeth index (DMFT) and plaque index, salivary flow rate, salivary $\mathrm{pH}$ and prevalence of white spot lesions were determined in 83 patients with different types of orthodontic brackets and ligation (metal passive self-ligating brackets, conventional metal brackets, mono-crystal brackets and polycrystalline active self-ligating brackets), before and six months after the beginning of fixed orthodontic treatment. The patients were recruited in a private dental office, in the period of two years. The group comprised 83 patients (mean age: $15.14 \pm 1.66$ years), including 52 women (mean age: $15.08 \pm 1.68)$ and 31 men $(15.24 \pm 1.64)$. Statistical analysis was performed by use of dependent and independent samples t-test as well as one way ANOVA, Wilcoxon signed rank test and the Kruskal Wallis test. P-values below 0.05 ( $p<0.05$ ) were considered significant. Results: DMFT and salivary flow have shown a significant increase, while salivary $\mathrm{pH}$ has shown a significant decrease in the observed time interval, in all patients irrespective of type of brackets and ligation. Among patients with different bracket material, no significant differences were found in any of the observed parameters. Conclusion: Although salivary flow rate is increased in patients with fixed orthodontic appliances which can have caries-protective effect, DMFT also increases and salivary $\mathrm{pH}$ decreases six months after the beginning of the treatment independently of bracket material or ligation type. All patients should receive instructions for precise oral hygiene and dietary habits before the beginning of fixed orthodontic therapy and at every dental check-up.
Received: March 13, 2019

Accepted: August 29, 2019

Address for correspondence Božana Lončar Brzak Sveučilište u Zagrebu Stomatološki fakultet Zavod za oralnu medicinu Gundulićeva 5, 10000 Zagreb loncar@sfzg.hr

\section{Key words}

Orthodontic Appliances; Orthodontic Brackets; Saliva; Hydrogen-Ion Concentration; DMF Index; Dental Plaque Index

\section{Introduction}

Fixed orthodontic treatment can have multiple effects on oral health. The placement of orthodontic appliances leads to easier accumulation of microorganisms and food residues, which when left over time, may cause development of white spot lesions, caries, gingivitis and exacerbate periodontal disease $(1,2)$. The process usually starts as enamel demineralization seen as white spots which further on might lead to the development of caries. Demineralization and remineralization processes are constantly taking place between tooth surfaces and accumulated plaque, due to saliva properties. Generally, salivary $\mathrm{pH}$ follows salivary flow rate. It is well known that lower $\mathrm{pH}$ in the oral cavity accelerates formation of aci-
Uvod

Terapija fiksnim ortodontskim napravama može višestruko utjecati na oralno zdravlje. Postavljanje ortodontskih naprava olakšava nakupljanje mikroorganizama i ostataka hrane, koji, kada su dulje ostavljeni, mogu uzrokovati nastanak bijelih mrlja, karijesa, gingivitisa i egzacerbacije parodontne bolesti $(1,2)$. Proces obično počinje kao demineralizacija cakline vidljiva kao bijele mrlje, čijim se napredovanjem može pojaviti karijes. Zahvaljujući svojstvima sline, procesi demineralizacije i remineralizacije konstantno traju između površine zuba i nakupljenog plaka. Općenito, $\mathrm{pH}$ sline slijedi količinu salivacije. Poznato je da niži $\mathrm{pH}$ u usnoj šupljini potiče nastanak aciduričnih bakterija (kao što su $S$. mutans i lakto- 
duric bacteria (such as S.mutans and Lactobacilli), while higher $\mathrm{pH}$ maintains higher buffer capacity, which in turn decreases caries incidence (3).

Self-ligating brackets do not require additional parts to support the archwires and dental hygiene since they are easily maintained compared to conventional brackets. Therefore, the accumulation of plaque and development of white spot lesions should be decreased. Of course, other contributing factors such as oral hygiene habits, nutrition and use of additional remineralizing agents could influence this process.

Do Nascimento et al. (4), on the basis of the systemic review, concluded that there is no evidence in the published literature that conventional or self-ligating brackets are different with regard to the colony formation and adhesion of Streptococcus mutans. The same finding was reported regarding the periodontal status in patients with different bracket systems by Arnolds et al. (5), while Yang et al. (6) reported that there were no differences in plaque control between conventional and self-ligating brackets according to the published literature.

The aim of this prospective longitudinal study was to evaluate the influence of fixed orthodontic treatment on clinical and salivary parameters. The primary outcome was to assess the prevalence of decayed, missing and filled teeth (DMFT) before, and six months after the beginning of fixed orthodontic treatment in patients with different types of brackets and ligation. The secondary outcome was to determine the effect of orthodontic therapy on plaque index, salivary $\mathrm{pH}$, salivary flow and the prevalence of white spot lesions in these patients.

\section{Material and methods}

This study was approved by the Ethical Committee of the School of Dental Medicine, University of Zagreb in Croatia (protocol approval number 36/2014.). All the participants signed informed consent according to Helsinki II. The inclusion criteria were that none of the patients was on the orthodontic therapy prior to this study, all upper frontal teeth were completely erupted, there were no signs of fillings or prosthetic structures on the buccal surfaces, participants were non-smokers and did not use any local therapies (antiseptics, fluorides or probiotics) during the last six months. The exclusion criteria were systemic diseases and oral piercing. The patients were recruited in a private dental office, in the period of two years. All patients who met inclusion and exclusion criteria and who signed informed consent were included in the study and randomly assigned to each of four treatment groups, depending on the type of brackets. A total of $83 \mathrm{pa}-$ tients were involved in the study (mean age: $15.14 \pm 1.66$ years), including 52 women (mean age: $15.08 \pm 1.68$ ) and 31 men $(15.24 \pm 1.64)$. Treatment planning and clinical practices were performed by a specialist orthodontist, A.J. There was neither allocation concealment nor blinding of the investigator.

Orthodontic therapy was carried out without extraction. Molar tubes were placed on first molar teeth. Conventional bracket dimension was 0.018 inch slot, and self-ligating 0.022 inch slot. There were 21 patients with monocrystalline bacili), a viši održava puferski kapacitet koji zauzvrat snižava incidenciju karijesa (3).

Samovezujuće bravice ne zahtijevaju dodatne dijelove za potporu lukova pa se dentalna higijena lakše održava u usporedbi s konvencionalnim bravicama. Stoga bi nakupljanje plaka i nastanak bijelih mrlja trebali biti smanjeni. Naravno, na taj proces mogu utjecati i drugi čimbenici kao što je održavanje oralne higijene, prehrana i primjena dodatnih remineralizirajućih sredstava.

Nascimento i suradnici (4) zaključili su na temelju sustavnog pregleda da u objavljenoj literaturi nema dokaza da postoji razlika u formiranju kolonija i adheziji Streptococcus mutans između konvencionalnih i samovezujućih bravica. Isto su zaključili i Arnolds i suradnci (5) u vezi s parodontnim statusom pacijenata s različitim vrstama bravica, a Yang i suradnici (6) istaknuli su da na temelju dosad objavljene literature nema razlika u kontroli plaka između konvencionalnih i samovezujućih bravica.

Cilj ovog prospektivnog longitudinalnog istraživanja bio je evaluirati utjecaj fiksne ortodontske terapije na kliničke i salivarne parametre. Primarno se željela ustanoviti prevalencija karioznih i ekstrahiranih zuba te zuba s ispunom (KEP indeksa) prije nego što se pacijentima postave fiksne ortodontske naprave $s$ različitim vrstama bravica i vezanja te šest mjeseci nakon toga postupka. Sekundarno se određivao učinak ortodontske terapije na indeks plaka, $\mathrm{pH}$ sline, količinu sline i prevalenciju bijelih mrlja kod tih pacijenata.

\section{Ispitanici i metode}

Istraživanje je odobrio Etički odbor Stomatološkog fakulteta Sveučilišta u Zagrebu (broj odobrenja: 36/2014). Svi sudionici potpisali su informirani pristanak prema Helsinškoj deklaraciji. Kriteriji za sudjelovanje bili su da nijedan od pacijenata prije nije bio na ortodontskoj terapiji; svi gornji prednji zubi potpuno su iznikli; na obraznim plohama nema znakova ispuna ili protetičkih restauracija; ispitanici su nepušači i nisu upotrebljavali lokalnu terapiju (antiseptike, fluoride ili probiotike) u posljednjih šest mjeseci. Kriterij za isključivanje bile su sustavne bolesti i oralni piercing. Pacijenti su birani u privatnoj stomatološkoj ordinaciji tijekom dvije godine. Svi koji su odgovarali kriterijima za sudjelovanje potpisali su informirani pristanak i uključeni su u istraživanje te nasumično raspoređeni u jednu od četiriju skupina, ovisno o vrsti bravica. U istraživanju su sudjelovala ukupno 83 pacijenta (srednja dob 15,14 $\pm 1,66$ godina) -52 žene (srednja dob 15,08 \pm $1,68)$ i 31 muškarac $(15,24 \pm 1,64)$. Planiranje terapije i klinički dio istraživanja obavila je specijalistica ortodoncije A. J. Nije bilo prikrivanja raspodjele, ni zasljepljivanja istraživača.

Ortodontska terapija provođena je bez ekstrakcija. Molarne cjevčice stavljene su na prve kutnjake. Dimenzija utora konvencionalne bravice bila je 0,018 inča, a samovezujućih 0,022 inča. Sudjelovao je ukupno 21 pacijent s monokristalnim keramičkim bravicama (Pure, Ortho Technology Inc., Tampa, FL, SAD), 21 pacijent s metalnim konvencionalnim bravicama (Mini Sprint Bracket, Forestadent Bernard Forster 
ceramic brackets (Pure, Ortho Technology Inc., Tampa, FL), 21 patients with metal conventional brackets (Mini Sprint Bracket, Forestadent Bernard Forster GmBH, Pforzheim, Germany), 21 patients with metal passive self-ligating brackets (Lotus plus, Ortho Technology Inc., Tampa, FL) and 20 patients with polycrystalline active self-ligating brackets (Sensation, Ortho Technology Inc., Tampa, FL).

All parameters were measured before the beginning of fixed orthodontic treatment and six months after the beginning of fixed orthodontic treatment. Decayed, missing and filled teeth (DMFT) indices were registered according to the World Health Organization, WHO (7). Caries was detected by visual-tactile examination and use of Diagnodent in cervical areas of teeth 13,12,11,21,23, 16, 43, 33, 36. The number of scored teeth was 32 per patient. Plaque was measured according to the modified Silness Loe index (8) on the teeth $16,12,24,44,32$. Unstimulated salivary flow rate was measured according to Navazesh et al. (9). Salivary pH was determined by $\mathrm{pH}$ strip which was immersed into the saliva sample for $10 \mathrm{~s}$, and the color change was used to estimate the remaining $\mathrm{pH}$ according to the scale provided by the manufacturer. Diagnosis of the white spot lesions was made by use of Diagnodent pen (DIAGNOdent Pen, Kavo, and Biberach, Germany) according to the manufacturer's recommendation. White spot lesions were included in DMFT index if they were clinically visible (Diagnodent score $>21$ ).

\section{Statistical analysis}

The Kolmogorov Smirnov test was used to assess if variables were normally distributed. Due to normal distribution of variables, dependent samples t-test and the Wilcoxon signed rank test were used for before/after comparisons. To assess differences within groups (among patients with different type of braces), one way ANOVA, the Kruskal Wallis and independent samples test were used. P-value below $0.05(\mathrm{p}<0.05)$ was considered statistically significant. The data were analyzed using SPSS version 20 Software.

\section{Results}

Significant difference in DMFT before the orthodontic treatment and six months after the beginning of the treatment was found $(\mathrm{p}<0.005)$. No significant difference in DMFT and plaque accumulation (assessed by Silness Loe index) before and after the beginning of treatment was found (Table 1) among patients with different brace material ( $\mathrm{Ta}-$ ble 1).

Median salivary $\mathrm{pH}$ before treatment was 7.7 (6.5-8.7) and 7.5 (6.5-8.4) after the treatment. A significant decrease was observed in salivary $\mathrm{pH}(\mathrm{p}=0.005$, Wilcoxon signed rank test). Among patients with different brace material, the difference in salivary $\mathrm{pH}$ in the observed time period was not significant ( $\mathrm{p}=0.726$ and 0.797 , Kruskal Wallis test) (Table 2).

Median salivary flow before the treatment was 0.5 (0.061.7) $\mathrm{ml} / \mathrm{min}$ and $0.6(0.1-9) \mathrm{ml} / \mathrm{min}$ after the beginning of treatment. Significant difference in salivary flow before and six months after the beginning of the treatment was found
GmBH, Pforzheim, Njemačka), 21 pacijent s metalnim pasivnim samovezujućim bravicama (Lotus plus, Ortho Techology Inc., Tampa, FL, SAD) i 20 pacijenata s polikristalnim aktivnim samovezujućim bravicama (Sensation, Ortho Technology Inc., Tampa, FL, SAD).

Svi parametri određeni su prije početka fiksne ortodontske terapije i šest mjeseci nakon njezina početka. Indeks karioznih i ekstrahiranih zuba te zuba s ispunom (KEP) zabilježen je prema kriterijima Svjetske zdravstvene organizacije (7). Karijes je detektiran vizualno-taktilnom metodom i primjenom Diagnodenta u područjima vratova zuba 13, 12, 11, 21, $23,16,43,33,36$. Broj pregledanih zuba po pacijentu bio je 32. Plak je mjeren prema modificiranom indeksu Silness Loe (8) na zubima 16, 12, 24, 44, 32. Nestimulirana količina sline određena je prema Navazeshu i suradnicima (9). Salivarni $\mathrm{pH}$ izmjeren je $\mathrm{pH}$ trakicom koja je bila uronjena u uzorak sline 10 sekunda, a promjena boje korištena je za procjenu $\mathrm{pH}$ u mirovanju prema mjernoj ljestvici proizvođača. Dijagnoza bijelih mrlja postavljena je primjenom Diagnodenta (DIAGNOdent Pen, Kavo, Biberach, Njemačka) prema preporukama proizvođača. Bijele mrlje bile su uključene u KEP indeks ako su bile klinički vidljive (vrijednost određena Diagnodentom $>21$ ).

\section{Statistička analiza}

Kolmogorov-Smirnovljev test korišten je za procjenu normalnosti raspodjele. $S$ obzirom na normalnu raspodjelu varijabli, za usporedbe prije i poslije postupka korišteni su t-test za zavisne uzorke i Wilcoxonov signed rank test. Za odredivanje razlika među skupinama (među pacijentima $s$ različitim vrstama bravica) korišsteni su jednosmjerna ANOVA, Kruskal-Wallisov test i test za nezavisne uzorke. P-vrijednost manja od $0,05(\mathrm{p}<0,05)$ smatrana je statistički značajnom. Podatci su analizirani primjenom verzije softvera 20 SPSS.

\section{Rezultati}

Ustanovljena je značajna razlika u KEP indeksu prije ortodontskog liječenja i šest mjeseci nakon toga postupka $(\mathrm{p}<$ $0,005)$. Među pacijentima $s$ različitim vrstama bravica prije liječenja i nakon toga nije uočena značajna razlika u KEP-indeksu i nakupljanju plaka (procijenjenom prema indeksu Silness Loe) (tablica 1.).

Medijan salivarnog $\mathrm{pH}$ prije tretmana bio je 7,7 (6,5$8,7)$ i $7,5(6,5-8,4)$ poslije tretmana. Uočen je značajan pad u salivarnom $\mathrm{pH}(\mathrm{p}=0,005$, Wilcoxonov signed rank test). Među pacijentima $s$ različitim vrstama bravica, razlika u salivarnom $\mathrm{pH}$ u promatranom razdoblju nije bila statistički značajna ( $\mathrm{p}=0,726$ i 0,797 , Kruskal-Wallisov test) (tablica 2.).

Medijan količine sline prije liječenja bio je $0,5(0,06$ $-, 1,7) \mathrm{ml} / \mathrm{min}$. i $0,6(0,1-9) \mathrm{ml} / \mathrm{min}$. poslije početka liječenja. Pronađena je značajna razlika u količini sline prije početka liječenja i šest mjeseci poslije ( $\mathrm{p}=0,005$, Wilcoxonov signed rank test), no nije bilo značajne razlike u količini sli- 
Table 1 DMFT and plaque accumulation before the treatment and six months after the beginning of the treatment, for all patients (t-test, $p<0.05)$ and all groups of patients ( $<<0.05$, One way ANOVA) $(I-$ Monocrystal ceramic brackets, II-Metal conventional brackets, IIIMetal passive self-ligating brackets, IV- Polycrystal active self-ligating brackets).

Tablica 1. KEP indeks i indeks nakupljanja plaka prije liječenja i šest mjeseci nakon toga za sve pacijente (t-test, $p<0,05)$ i sve skupine pacijenata ( $<<0,05$, jednosmjerna ANOVA) (I.- monokristalne keramičke bravice, II. - metalne konvencionalne bravice, III. - metalne pasivne samovezujuće bravice, IV. - polikristalne aktivne samovezujuće bravice)

\begin{tabular}{|c|c|c|c|c|}
\hline Bracket type $\bullet$ Vrsta bravice & $\begin{array}{l}\text { DMFT before } \\
\text { KEP prije }\end{array}$ & $\begin{array}{l}\text { DMFT after } \\
\text { KEP poslije }\end{array}$ & $\begin{array}{l}\text { Silness Loe before } \\
\text { Silness Loe prije }\end{array}$ & $\begin{array}{l}\text { Silness Loe after } \\
\text { Silness Loe poslije }\end{array}$ \\
\hline I & $4.43 \pm 4.3$ & $5 \pm 4.54$ & $0.30 \pm 0.23$ & $0.37 \pm 0.28$ \\
\hline II & $7.71 \pm 4.43$ & $5 \pm 4.54$ & $8.01 \pm 5.35$ & $5.48 \pm 5.14$ \\
\hline III & $0.40 \pm 0.31$ & $0.30 \pm 0.23$ & $0.37 \pm 0.34$ & $0.44 \pm 0.28$ \\
\hline IV & $0.5 \pm 0.27$ & $0.37 \pm 0.28$ & $0.32 \pm 0.36$ & $0.40 \pm 0.24$ \\
\hline Mean square $\bullet$ Srednji kvadrat & 38.556 & 0.075 & 50.075 & 0.134 \\
\hline $\mathrm{F}$ & 1.979 & 0.874 & 2.101 & 1.577 \\
\hline $\mathrm{p}(\mathrm{df}=3)$ & 0.124 & 0.458 & 0.107 & 0.201 \\
\hline All types of brackets $\bullet$ Sve vrste bravica & $5.79 \pm 4.49$ & $6.56 \pm 4.98$ & $0.38 \pm 0.29$ & $0.4 \pm 0.29$ \\
\hline $\mathrm{p}$ & \multicolumn{2}{|c|}{$<0.001$} & \multicolumn{2}{|c|}{0.585} \\
\hline $\begin{array}{l}95 \% \text { CI } \\
\text { Lower • Donja } \\
\text { Upper • Gornja } \\
\end{array}$ & \multicolumn{2}{|c|}{$\begin{array}{l}-1.09 \\
-0.45\end{array}$} & \multicolumn{2}{|c|}{$\begin{array}{l}-0.1 \\
0.06\end{array}$} \\
\hline
\end{tabular}

Table 2 Salivary pH and prevalence of white spot lesions (WSL) before and six months after beginning of treatment in all patients (salivary $\mathrm{pH}: \mathrm{p}=0.005$, the Wilcoxon signed rank test; prevalence of WSL: $p=0.723$, chi-square test) and in all groups of patients (salivary $\mathrm{pH}$ : $p=0.726, p=0.797$, Kruskal-Wallis test; prevalence of WSL: $p=4.293$, the Pearson chi-square test) (1- Monocrystal ceramic brackets, II-Metal conventional brackets, III- Metal passive self-ligating brackets, IV- Polycrystal active self-ligating brackets).

Tablica 2. Salivarni pH i prevalencija bijelih mrlja (engl. white spot lesions - WSL) prije početka liječenja i šest mjeseci poslije kod svih pacijenata (salivarni $\mathrm{pH}: \mathrm{p}=0,005$, Wilcoxonov signed rank test; prevalencija bijelih mrlja: $p=0,723$, hi-kvadrat test) i u svim skupinama pacijenata (salivarni $\mathrm{pH}: \mathrm{p}=0,726, \mathrm{p}=0,797$, Kruskal-Wallisov test; prevalencija bijelih mrlja: $\mathrm{p}=4,293$, Pearsonov hi-kvadrat test) (I. - monokristalne keramičke bravice, II. - metalne konvencionalne bravice, III. - metalne pasivne samovezujuće bravice, IV. - polikristalne aktivne samovezujuće bravice).

\begin{tabular}{|c|c|c|c|c|c|c|c|c|c|c|c|c|c|}
\hline \multirow[b]{2}{*}{$\begin{array}{c}\text { Bracket } \\
\text { type } \bullet \text { Vrsta } \\
\text { bravice }\end{array}$} & \multirow[b]{2}{*}{$\mathbf{N}$} & \multicolumn{4}{|c|}{$\mathrm{pH}$ before $\bullet \mathrm{pH}$ prije } & \multicolumn{4}{|c|}{$\mathrm{pH}$ after $\bullet \mathrm{pH}$ poslije } & \multicolumn{4}{|c|}{ WSL } \\
\hline & & $\begin{array}{c}\text { Median • } \\
\text { Med. }\end{array}$ & Min. & $\begin{array}{l}\text { Max.• } \\
\text { Maks. }\end{array}$ & $\underset{(d \mathbf{f}=3)}{p}$ & $\begin{array}{c}\text { Median • } \\
\text { Med. }\end{array}$ & Min. & $\begin{array}{l}\text { Max.• } \\
\text { Maks. }\end{array}$ & $\underset{(\mathbf{d} \mathbf{f}=3)}{\mathbf{p}}$ & $\begin{array}{l}\text { WSL before • } \\
\text { WSL prije } \\
(\mathrm{N}, \%)\end{array}$ & $\begin{array}{l}\text { WSL after • } \\
\text { WSL poslije } \\
(\mathrm{N}, \%)\end{array}$ & $\begin{array}{c}\text { chi- } \\
\text { square } \\
\text { hi- } \\
\text { kvadrat }\end{array}$ & $\underset{(d f=3)}{p}$ \\
\hline I & 21 & 6.1 & 3.5 & 7.0 & \multirow[b]{4}{*}{0.726} & 6.3 & 2.5 & 7 & \multirow[b]{4}{*}{0.797} & $18(85.7 \%)$ & $3(14.3 \%)$ & \multirow[b]{4}{*}{4.293} & \\
\hline II & 21 & 6.1 & 5.2 & 7 & & 6.5 & 5.5 & 7 & & $14(66,7 \%)$ & $7(33,3 \%)$ & & \\
\hline III & 21 & 6 & 4.7 & 7 & & 6.5 & 5.3 & 7 & & $19(90.5 \%)$ & $2(9.5 \%)$ & & \\
\hline IV & 20 & 5.85 & 5.4 & 4.5 & & 5.85 & 5.3 & 7.2 & & $16(80,0 \%)$ & $4(20,0 \%)$ & & \\
\hline $\begin{array}{l}\text { Total } \bullet \\
\text { Ukupno }\end{array}$ & 83 & 6 & 3.5 & 8.5 & & 6.5 & 2.5 & 7.2 & 0.005 & $67(80,7 \%)$ & $16(19,3 \%)$ & & 0.723 \\
\hline
\end{tabular}

Table 3 Salivary flow before the treatment and six months after the beginning of the treatment, in all patients ( $p=0.005$, Wilcoxon signed rank test) and in all groups of patients $(\mathrm{p}<0.05$, the Kruskal Wallis test) (I- Monocrystal ceramic brackets, II-Metal conventional brackets, III- Metal passive self-ligating brackets, IV- Polycrystal active self-ligating brackets).

Tablica 3. Količina sline prije početka liječenja i šest mjeseci poslije kod svih pacijenata ( $p=0,005$, Wilcoxonov signed rank test) i u svim skupinama pacijenata ( $<<0,05$, Kruskal Wallisov test) (I. - monokristalne keramičke bravice, II. - metalne konvencionalne bravice, III. - metalne pasivne samovezujuće bravice, IV. - polikristalne aktivne samovezujuće bravice).

\begin{tabular}{|c|c|c|c|c|c|c|c|c|c|c|c|}
\hline \multirow[b]{2}{*}{$\begin{array}{l}\text { Bracket type } \\
\text { Vrsta bravice }\end{array}$} & \multirow[b]{2}{*}{$\mathbf{N}$} & \multicolumn{5}{|c|}{$\mathrm{QS}$ before $\bullet \mathrm{QS}$ prije $(\mathrm{ml} / \mathrm{min})$} & \multicolumn{5}{|c|}{ QS after $\bullet Q S$ poslije $(\mathrm{ml} / \mathrm{min})$} \\
\hline & & $\begin{array}{c}\text { Median • } \\
\text { Med. }\end{array}$ & Min. & $\begin{array}{l}\text { Max. } \\
\text { Maks. }\end{array}$ & $95 \% \mathrm{CI}$ & $p(d f=3)$ & $\begin{array}{c}\text { Median • } \\
\text { Med. }\end{array}$ & Min. & $\begin{array}{l}\text { Max. } \\
\text { Maks. }\end{array}$ & $95 \% \mathrm{CI}$ & $\mathrm{p}(\mathrm{df}=3)$ \\
\hline I & 21 & 0.5 & 0.06 & 0.98 & $\begin{array}{l}0.3913 \\
0.6449\end{array}$ & \multirow[b]{4}{*}{0.462} & 0.6 & 0.13 & 9.00 & $\begin{array}{l}0.2722 \\
1.9440\end{array}$ & \multirow[b]{4}{*}{0.316} \\
\hline II & 21 & 0.48 & 0.08 & 1.02 & $\begin{array}{l}0.3557 \\
0.6120\end{array}$ & & 0.5 & 0.20 & 1.30 & $\begin{array}{l}0.4520 \\
0.7328\end{array}$ & \\
\hline III & 21 & 0.54 & 0.24 & 1.56 & $\begin{array}{l}0.4936 \\
0.8217\end{array}$ & & 0.6 & 0.10 & 1.60 & $\begin{array}{l}0.5792 \\
0.9770\end{array}$ & \\
\hline IV & 20 & 0.46 & 0.10 & 1.70 & $\begin{array}{l}0.3978 \\
0.7642\end{array}$ & & 0.6 & 0.20 & 1.50 & $\begin{array}{l}0.5245 \\
0.9067\end{array}$ & \\
\hline Total $\bullet$ Ukupno & 83 & 0.55 & 0.06 & 1.70 & $\begin{array}{l}0.4875 \\
0.6323\end{array}$ & & 0.79 & 0.10 & 9.00 & $\begin{array}{l}0.5847 \\
1.0144\end{array}$ & 0.005 \\
\hline
\end{tabular}


( $p=0.005$, Wilcoxon signed rank test), but there was no significant difference in salivary flow among patients with different brace material before and after the beginning of treatment ( $\mathrm{p}=0.462, \mathrm{p}=0.316$, Kruskal Wallis test) (Table 3 ).

The prevalence of white spot lesions was noticed in $19.3 \%(67 / 83)$ of patients before the treatment and in $33.7 \%$ (28/83) of patients six months after the beginning of the treatment. No significant difference was found in the prevalence of white spot lesions in all patients before and after the treatment $(\mathrm{p}=0.723$, chi-square test), nor among patients with different brace material, in this time interval $(\mathrm{df}=3$, $\mathrm{p}=4.293$, Pearson chi-square test) (Table 2).

\section{Discussion}

The results from the literature review on comparison of clinical and salivary findings in orthodontic patients with different bracket types differ. Some authors point out that selfligating brackets show more advantages than conventional brackets, in terms of oral health $(1,10-12)$. On the contrary, the results of our study have not found significant difference in DMFT, plaque accumulation, median salivary flow, median salivary $\mathrm{pH}$ or prevalence of white spot lesions in patients with different types of brackets and ligation.

The primary aim of our study was to assess the prevalence of DMFT before and six months after the beginning of fixed orthodontic treatment in patients with different types of brackets and ligation. Sudarevic et al. (13) reported a significant increase in DMFT index 12 weeks after the placement of fixed appliances. This is in concordance with our results which have shown significant increase in DMFT index six months after the beginning of the treatment in all patients $(p<0.001)$, although we did not observe a statistically significant difference among patients with different brace material or ligation type. We observed a significant increase only in DMFT and salivary flow, while we observed a significant decrease of salivary $\mathrm{pH}$. The increase in DMFT could be explained by significantly lowered $\mathrm{pH}$ and slightly higher plaque index. Also, our results indicate that increased salivary flow is not sufficient to decrease the risk for caries, and that other factors also influence oral health in orthodontic patients. The limitation of our study is that the number of participants was not calculated based on a power analysis, and we are aware of the fact that this diminishes the reliability of our results.

The second aim of our study was to determine the effect of orthodontic therapy on plaque index, salivary $\mathrm{pH}$, salivary flow and the prevalence of white spot lesions.

Lindel et al. (14) reported that ceramic brackets tend to accumulate less long-term biofilm compared to the metal ones. Other authors $(2,13,15)$ have not found significant difference in visible plaque index in patients with different types of brackets, which is also in concordance with our results. Plaque index was slightly, but not significantly, increased in the observed period in all patients, irrelevant of the bracket type. Our findings could be explained by the precise instructions in oral hygiene measures during each checkup and the resolving of crowding during the first 6 months ne među pacijentima $s$ različitim vrstama bravica prije početka liječenja i šest mjeseci poslije ( $\mathrm{p}=0,462, \mathrm{p}=0,316$, Kruskal-Wallisov test) (tablica 3.).

Prevalencija bijelih mrlja ustanovljena je kod 19,3\% (67/83) pacijenata prije liječenja i kod 33,7 \% (28/83) šest mjeseci nakon početka liječenja. Nije nađena značajna razlika u prevalenciji bijelih mrlja kod svih pacijenata prije početka liječenja i šest mjeseci poslije ( $\mathrm{p}=0,723$, hi-kvadrat test), ni među pacijentima s različitim vrstama bravica u tom razdoblju (df $=3, p=4,293$, Pearsonov hi-kvadrat test) (tablica 2.).

\section{Rasprava}

Rezultati iz literature razlikuju se nakon usporedbe kliničkih i salivarnih nalaza ortodonstkih pacijenata s različitim vrstama bravica. Neki autori ističu da samovezujuće bravice imaju više prednosti negoli konvencionalne, kad je riječ o oralnome zdravlju $(1,10-12)$. Nasuprot tomu, rezultati našeg istraživanja nisu pokazali značajnu razliku u KEP-indeksu, nakupljanju plaka, količini sline, medijanu salivarnog $\mathrm{pH}$ ili prevalenciji bijelih mrlja kod pacijenata $s$ različitim vrstama bravica i vezanja.

Primarni cilj ovog istraživanja bio je ustanoviti KEP indeks prije početka fiksne ortodontske terapije i šest mjeseci poslije kod pacijenata s različitim vrstama bravica i vezanja. Sudarević i suradnici (13) uočili su značajan porast KEP-indeksa 12 tjedana nakon postavljanja fiksnih naprava. To je u skladu s našim rezultatima koji su pokazali značajan porast KEP indeksa šest mjeseci nakon početka liječenja kod svih ispitanika $(\mathrm{p}<0,001)$, premda nismo zapazili značajnu razliku među pacijentima s različitim vrstama bravica i načina vezanja. KEP indeks i količina sline jedina su dva parametra za koje smo uočili značajan porast, a kod pH sline zabilježeno je značajno smanjenje. Porast KEP indeksa mogli bismo objasniti značajno sniženim $\mathrm{pH}$ i blago povišenim indeksom plaka. Naši rezultati također upućuju na to da porast količine sline nije dovoljan da smanji rizik od karijesa te da i drugi čimbenici utječu na oralno zdravlje ortodontskih pacijenata. Ograničenje našeg istraživanja jest to što broj ispitanika nije određen na temelju snage testa i svjesni smo da to umanjuje pouzdanost naših rezultata.

Sekundarno se u našem istraživanju želio ustanoviti učinak ortodontske terapije na indeks plaka, $\mathrm{pH}$ sline, količinu sline i prevalenciju bijelih mrlja.

Lindel i suradnici (14) istaknuli su da keramičke bravice nakupljaju manje dugoročnog biofilma u usporedbi s metalnima. Drugi autori $(2,13,15)$ nisu pronašli značajnu razliku $\mathrm{u}$ vidljivom indeksu plaka kod pacijenata s različitim vrstama bravica, što je također u skladu s našim rezultatima. Indeks plaka bio je lagano, no ne znatno, povećan kod svih pacijenata u promatranom razdoblju, neovisno o vrsti bravica. Naš nalaz može se objasniti detaljnim uputama o oralnoj higijeni tijekom svake kontrole i rješavanjem zbijenosti zuba u prvih šest mjeseci ortodontske terapije, ali se također može pripisati Hawthornovu učinku (svijesti pacijenta da ga se pregledava i evaluira). 
of orthodontic treatment, but they can also be attributable to the Hawthorne effect (patients' awareness of being examined and evaluated).

Salivary $\mathrm{pH}$ was significantly decreased, which could be explained by our results of slightly increased plaque index measurements. More plaque deposits elevate acid levels in saliva, resulting in $\mathrm{pH}$ decrease. Consequently, physiologic response to maintain intraoral homeostatic conditions is to increase salivary flow rate, as seen in our results.

Unstimulated salivary flow was significantly increased for six months after the beginning of the treatment. This is partially consistent with the results of Arab et al. (16), which have shown gradual increase in unstimulated salivary flow rate at different time points, but their final measurement was at 18 th week, and the increase was at that point not (yet) statistically significant. Some of the authors report significant increase only in stimulated salivary flow rate $(17-19,20)$, while others reported unchanged salivary flow rate (21) in patients with fixed orthodontic appliances. Also, all of the above mentioned studies assessed salivary flow rate at different time intervals and included smaller number of participants than in our study. It appears that fixed orthodontic appliances do not have the same intensity of mechanostimulatory effect in all patients, and that the effect is likely to change over time.

The prevalence of WSL after the beginning of orthodontic therapy was shown in $33.7 \%$ of our patients, which is similar to the results of Enia et al. (21) and Khalaf (22) who found the prevalence of WSL in $32.3 \%$ and $42 \%$ of patients. We have not observed statistically significant difference when compared to the prevalence of WSL before orthodontic therapy, nor between different types of brackets. It is known that oral hygiene habits are directly linked to the development of WSL $(15,21)$, and our groups of patients did not differ significantly by the results of plaque accumulation which could initiate enamel demineralization. Oral hygiene habits are most important factor for maintaining oral health in patients undergoing fixed orthodontic treatment.

\section{Conclusions}

It is shown that treatment with fixed orthodontic appliances, irrespective of bracket type and ligation, may influence intraoral homeostasis, as DMFT and salivary flow significantly increased while salivary $\mathrm{pH}$ significantly decreased in all groups of patients. In order to prevent from irreversible changes occurring in teeth, such as development of white spot and carious lesions, all patients should receive instructions for precise oral hygiene and dietary habits before the beginning of fixed orthodontic therapy and on every control examination.

\section{Conflict of interest}

None declared.
Salivarni pH bio je značajno snižen, što se može objasniti našim rezultatima lagano povišenih vrijednosti pri mjerenju indeksa plaka. Veće naslage plaka potiču porast razine kiselina u slini, što ima za posljedicu sniženje $\mathrm{pH}$. Kao rezultat toga, fiziološki odgovor za održavanje uvjeta intraoralne homeostaze jest da se poveća količina sline, kao što je vidljivo u našim rezultatima.

Nestimulirana količina sline bila je značajno povećana šest mjeseci nakon početka liječenja. To je dijelom u skladu s rezultatima Araba i suradnika (16) koji su pokazali postupni porast količine nestimulirane sline u različitim vremenskim intervalima, no njihovo posljednje mjerenje bilo je nakon 18 tjedana kada porast (još) nije bio statistički značajan. Neki autori istaknuli su znatni porast samo stimulirane količine sline $(17-19,20)$, a drugi nisu uočili promjenu u njezinoj količini (21) kod pacijenata s fiksnim ortodontskim napravama. U svim spomenutim studijama procjenjivale su se količine sline u različitim intervalima i uključivale su manji broj ispitanika negoli naša studija. Čini se da fiksne ortodontske naprave nemaju isti intenzitet mehanostimulatornog učinka na sve pacijente i možda se učinak $s$ vremenom promijeni.

Prevalencija bijelih mrlja nakon početka ortodontske terapije kod naših pacijenata bila je 33,7 \%, što je slično rezultatima Enie i suradnika (21) te Khalafa (22) koji su pronašli prevalenciju bijelih mrlja kod 32,3\% i $42 \%$ pacijenata. Nismo pronašli statistički značajnu razliku u usporedbi s prevalencijom bijelih mrlja prije ortodontske terapije ni među pacijentima s različitim vrstama bravica. Poznato je da su navike u održavanju oralne higijene izravno povezane s razvojem bijelih mrlja $(15,21)$ i naše skupine pacijenata nisu se značajno razlikovale u usporedbi $s$ rezultatima nakupljanja plaka koji bi mogli potaknuti demineralizaciju cakline. Oralne higijenske navike najvažniji su čimbenik za održavanje oralnoga zdravlja pacijenata na fiksnoj ortodontskoj terapiji.

\section{Zaključak}

Pokazalo se da tretman fiksnim ortodontskim napravama, neovisno o vrsti bravica i načinu vezanja, može utjecati na intraoralnu homeostazu zato što su KEP indeks i količina sline značajno porasli, a $\mathrm{pH}$ sline značajno se smanjio u svim skupinama pacijenata. Da bi se spriječile nepovratne promjene na zubima, poput razvoja bijelih mrlja i karioznih lezija, svi pacijenti trebaju dobiti detaljne upute o oralnoj higijeni i prehrambenim navikama prije početka fiksne ortodontske terapije i na svakom kontrolnom pregledu.

\section{Sukob interesa}

Autori nisu bili u sukobu interesa. 
Sažetak

Cilj: Podatci o kliničkim i salivarnim nalazima pacijenata s različitim vrstama ortodontskih bravica i vezanja (ligacije) doista su oskudni. Zbog toga je cilj ove studije bio usporediti kliničke i salivarne nalaze pacijenata s različitim vrstama fiksnih ortodontskih naprava. Ispitanici i postupci: Indeks karioznih i ekstrahiranih zuba te zuba s ispunom (KEP indeks), indeks plaka, količina sline, pH sline i prevalencija bijelih mrlja određena je za 83 pacijenta s različitim vrstama ortodontskih bravica i vezanja (metalne pasivne samovezujuće bravice, konvencionalne metalne bravice, monokristalne bravice i polikristalne aktivne samovezujuće bravice), prije početka ortodontske terapije i poslije toga tretmana. Pacijenti su, u razdoblju od dvije godine, birani u privatnoj stomatološkoj ordinaciji. Skupinu su činila 83 pacijenta (srednja dob 15,14 \pm 1,66 godina) - 52 žene (srednja dob 15,8 $\pm 1,68$ ) i 31 muškarac (srednja dob 15,24 $\pm 1,64$ ). Statistička analiza rađena je primjenom t-testova za zavisne i nezavisne uzorke te jednosmjernog testa ANOVA-e, Wilcoxonova signed rank testa i Kruskal-Wallisova testa. P-vrijednost manja od $0,05(p<0,05)$ smatrana je statistički značajnom. Rezultati: KEP indeks $i$ količina sline pokazali su značajan porast, a pH sline značajno se snizio u promatranom razdoblju kod svih pacijenata, neovisno o vrsti bravica i ligacije. Nije nađena statistički značajna razlika u promatranim parametrima među pacijentima s različitim ortodontskim bravicama. Zaključak: lako je količina salivacije povećana kod pacijenata s fiksnim ortodontskim napravama, što može imati protektivni protukarijesni učinak, KEP indeks također raste, a pH sline pada šest mjeseci nakon početka tretmana, neovisno o materijalu bravica i načinu vezanja. Svi pacijenti trebali bi dobiti detaljne pute o oralnoj higijeni i prehrambenim navikama prije početka fiksne ortodontske terapije i na svakom kontrolnom pregledu.
Zaprimljen: 13. ožujka 2019.

Prihvaćen: 29. kolovoza 2019.

Adresa za dopisivanje

Božana Lončar Brzak

Sveučilište u Zagrebu

Stomatološki fakultet

Zavod za oralnu medicinu

Gundulićeva 5, 10000 Zagreb

loncar@sfzg.hr

Ključne riječi

ortodontske naprave; ortodontske bravice; slina; koncentracija vodikovih iona; KEP indeks; indeks zubnog plaka

\section{References}

1. Nalçacı R, Özat Y, Çokakoğlu S, Türkkahraman H, Önal S, Kaya S. Effect of bracket type on halitosis, periodontal status, and microbial colonization. Angle Orthod. 2014 May;84(3):479-85.

2. Folco AA, Benítez-Rogé SC, Iglesias M, Calabrese D, Pelizardi C, Rosa A, et al. Gingival response in orthodontic patients: Comparative study between self-ligating and conventional brackets. Acta Odontol Latinoam. 2014;27(3):120-4.

3. Selwitz RH, Ismail Al, Pitts NB. Dental caries. Lancet. 2007 Jan 6;369(9555):51-9.

4. Do Nascimento LE, de Souza MM, Azevedo AR, Maia LC. Are selfligating brackets related to less formation of Streptococcus mutans colonies? A systematic review. Dental Press J Orthod. 2014 Jan-Feb;19(1):60-8.

5. Arnold S, Koletsi D, Patcas R, Eliades T. The effect of bracket ligation on the periodontal status of adolescents undergoing orthodontic treatment. A systematic review and meta-analysis. J Dent. 2016 Nov;54:13-24.

6. Yang X, Su N, Shi Z, Xiang Z, He Y, Han X, et al. Effects of self-ligating brackets on oral hygiene and discomfort: a systematic review and meta-analysis of randomized controlled clinical trials. Int J Dent Hyg. 2017 Feb;15(1):16-22.

7. WHO. Oral health surveys: basic methods. 4 th ed. Geneva;1997.

8. Silness J, Loe H. Periodontal disease in pregnancy. II. Correlation between oral hygiene and periodontal condition. Acta Odontol Scand. 1964 Feb;22:121-35.

9. Navazesh M. Methods for collecting saliva. Ann N Y Acad Sci 1993;694:72-77.

10. Shi J, Liu Y, Hou J, Yan Z, Peng H, Chang X. Comparison of periodontal indices and Porphyromonas gingivalis between conventional and self-ligating brackets. Hua Xi Kou Qiang Yi Xue Za Zhi. 2013 Jun;31(3):228-31.

11. Moolya NN, Shetty A, Gupta N, Gupta A, Jalan V, Sharma R. Orthodontic bracket designs and their impact on microbial profile and periodontal disease: A clinical trial. J Orthod Sci. 2014 Oct;3(4):125-31.

12. Akin M, Tezcan M, Ileri Z, Ayhan F. Incidence of white spot lesions among patients treated with self- and conventional ligation systems. Clin Oral Investig. 2015 Jul;19(6):1501-6.
13. Sudarević K, Jurela A, Repić D, Jokić D, Mikić IM, Pejda S. Oral health changes during early phase of orthodontic treatment. Acta Clin Croat. 2014 Dec;53(4):399-404.

14. Cardoso AA, Lopes LM, Rodrigues LP, Teixeira JJ, Steiner-Oliveira $C$, Nobre-Dos-Santos M. Influence of salivary parameters in the caries development in orthodontic patients-an observational clinical study. Int J Paediatr Dent. 2017 Nov;27(6):540-550.

15. Baka ZM, Basciftci FA, Arslan U. Effects of 2 bracket and ligation types on plaque retention: a quantitative microbiologic analysis with real-time polymerase chain reaction. Am J Orthod Dentofacial Orthop. 2013 Aug;144(2):260-7.

16. Arab S, Nouhzadeh Malekshah S, Abouei Mehrizi E, Ebrahimi Khanghah A, Naseh R, Imani MM. Effect of Fixed Orthodontic Treatment on Salivary Flow, pH and Microbial Count. J Dent (Tehran). 2016 Jan;13(1):18-22.

17. Chang HS, Walsh LJ, Freer TJ. The effect of orthodontic treatment on salivary flow, $\mathrm{pH}$, buffer capacity, and levels of mutans streptococci and lactobacilli. Aust Orthod J. 1999 Apr;15(4):229-34.

18. Lara-Carrillo E, Montiel-Bastida NM, Sánchez-Pérez L, Alanís-Tavira J. Effect of orthodontic treatment on saliva, plaque and the levels of Streptococcus mutans and Lactobacillus. Med Oral Patol Oral Cir Bucal. 2010 Nov 1;15(6):e924-9.

19. Peros K, Mestrovic S, Anic-Milosevic S, Slaj M. Salivary microbial and nonmicrobial parameters in children with fixed orthodontic appliances. Angle Orthod. 2011 Sep;81(5):901-6.

20. Cardoso AA, Lopes LM, Rodrigues LP, Teixeira JJ, Steiner-Oliveira $C$, Nobre-Dos-Santos M. Influence of salivary parameters in the caries development in orthodontic patients-an observational clinical study. Int J Paediatr Dent. 2017 Nov;27(6):540-550.

21. Enia M, Bock N, Ruf S. White-spot lesions during multibracket appliance treatment: a challenge for clinical excellence. Am J Orthod Dentofacial Orthop. 2011 Jul;140(1):e17-24.

22. Khalaf K. Factors Affecting the Formation, Severity and Location of White Spot Lesions during Orthodontic Treatment with Fixed Appliances. J Oral Maxillofac Res. 2014 Apr 1;5(1):e4. 